УДК 343.2

DOI https://doi.org/10.32849/2663-5313/2020.3.41

Ірина Давидович,

канд. юрид. наук, дочент,

доцент кафедри кримінального права та кримінологї

Київського начіонального університету імені Тараса Шевченка

\title{
ПОМ'ЯКШЕННЯ ПРИЗНАЧЕНОГО ПОКАРАННЯ ВНАСЛІДОК ЗВОРОТНОЇ ДІЇ КРИМІНАЛЬНОГО ЗАКОНУ: ПРОБЛЕМИ ЗАСТОСУВАННЯ Ч. 3 СТ. 74 КРИМІНАЛЬНОГО КОДЕКСУ УКРАЇНИ
}

Стаття присвячена практичним аспектам застосування інституту пом'якшення призначеного покарання внаслідок зворотної дії кримінального закону. Досліджується правова природа і нормативний зміст передбаченого ч. $3 \mathrm{~cm} .74$ КК положення про зменшения міри покарання засудженому, встановлюється алгоритм пом'якшення покарання $3 а$ ч. $3 \mathrm{~cm} .74 \mathrm{KK}$, визначається конкретний зміст поняття «максимальна межа покарання, встановленого санкиією нового закону». На думку автора, застосування положень ч. $3 \mathrm{~cm} .74$ КК може бути ускладнене у таких ситуачіях: 1) якщо максимальна межа покарання, встановлена санкиією нового закону, передбачає такий вид покарання, який в принципі не може бути призначений конкретній особі з огляду на ї вік, стать, стан здоров'я, вид професійної діяльності, наявність дітей певного віку та інші фактори, визначені статтями Розділу Х Загальної частини КК, але водночас санкиія нового закону містить альтернативні види покарання, допустимі для призначення відповідній особі; 2) якщо санкиія нового закону передбачатиме лише такі покарання, жодне з яких не може бути призначене конкретній особі з урахуванням обмежень, встановлених положеннями Розділу Х Загальної частини КК; 3) якщо максимальна межа покарання, встановлена санкиією нового закону, становить більш м'який вид покарання і перерахування цвого виду покарання в інші за правилами, встановленими ч. $1 \mathrm{~cm} .72$ КК, в приниипі не можливо (йдеться про такі види покарання, як штраф та позбавлення права обіймати певні посади або займатися певною діяльністю); 4) якщо міра покарання була визначена особі за правилами, передбаченими ст.ст. 70, 71 КК; 5) якщо засуджений був звільнений від відбування призначеного йому основного покарання з випробуванням. У статті запропоновані конкретні варіанти розв'язання наведених проблемних ситуацій.

Ключові слова: зворотна дія кримінального закону, кримінальний закон, кримінальна відповідальність, пом'якшення кримінальної відповідальності, пом'якшення призначеного покарання.

Постановка проблеми. Частина 3 ст. 74 КК передбачає спеціальні правила ретроактивного застосування нового кримінального закону, який пом'якшує покарання, щодо осіб, які на момент набрання чинності новим законом вже були засуджені та ще не відбули призначене їм покарання. В українській доктрині кримінального права положення ч. 3 ст. 74 КК небезпідставно розглядаються як один із видів звільнення від покарання та його відбування. Підстави для цього дає назва Розділу XII Загальної частини КК, до складу якого й входить ст. 74 КК. Варто, однак, зауважити, що формула «звільнення від покарання та його відбування» не досить добре передає суть правових наслідків, передбачених ч. 3 ст. 74 КК. На нашу думку, в даному випадку коректніше було б вести мову про пом'якшення покарання після його призначення. Зауважимо, що в цій формулі слова «після його призначення» мають принципове значення. Окремі іноземні автори, зокрема автори з пострадянського простору, пропонують розглядати положення, подібні за змістом до ч. 3 ст. 74 КК, як складник інституту призначення покарання. На наш погляд, 3 таким висновком не можна погодитися. Хоча пом'якшення покарання може мати місце й під час його призначення (наприклад, на підставі ст. 69 КК), положення ч. 3 ст. 74 КК «спрацьовують» на більш пізньому етапі кримінально-правового регулювання та кримінального провадження, а саме тоді, коли особу вже було засуджено та їй було призначено покарання. Таким чином, найбільш точно відбиває суть правових наслідків, передбачених ч. 3 ст. 74 КК формулювання «пом'якшення призначеного покарання», яким ми і будемо послуговуватися в цій публікації. 
Аналіз останніх публікацій та досліджень. Положення ч. 3 ст. 74 КК вже неодноразово ставали предметом уваги українських науковців. Причому вони розглядалися як на рівні підручників i науково-практичних коментарів до КК, так і на рівні дисертаційних досліджень (О.П.Горох Є. О. Письменський). Однак, як видається, поза увагою доктрини кримінального права залишаються проблеми застосування положень ч. 3 ст. 74 КК. Великий пласт конкретних прикладних питань застосування цих положень не розглядається в наукових та науково-практичних джерелах, хоча з точки зору потреб судової практики саме ці питання, а не, скажімо, питання про природу положень ч. 3 ст. 74 КК, є максимально актуальними.

Мета публікації полягає не в тому, щоб ще раз розглянути питання про юридичну природу правових наслідків, передбачених ч. 3 ст. 74 КК, і навіть не в тому, щоб виявити та продемонструвати їі недоліки та прогалини, а в тому, щоб встановити проблеми, які виникають у разі застосування положень ч. 3 ст. 74 КК, та запропонувати шляхи їх вирішення з огляду на актуальний ॥ стан кримінального законодавства.

Виклад основного матеріалу. Перед тим, як перейти до виконання поставлених завдань, наведемо ті вихідні положення, якими будемо керуватись у межах цього дослідження:

1) за своєю правовою природою передбачене ч. 3 ст. 74 КК положення про зменшення міри покарання засудженому є конкретним проявом закріпленого у ч. 1 ст. 5 КК принципу зворотної дії закону в часі, згідно з яким закон про кримінальну відповідальність, що скасовує злочинність діяння, пом'якшує кримінальну відповідальність або іншим чином поліпшує становище особи, має зворотну дію у часі, тобто поширюється на осіб, які вчинили відповідні діяння до набрання таким законом чинності, у тому числі на осіб, які відбувають покарання або відбули покарання, але мають судимість. У зв'язку з цим постає питання про можливість визнання «нового» кримінального закону таким, що пом'якшує покарання (lex in mitius). 3 огляду на значну кількість проведених досліджень (див. із цього приводу роботи М. І. Блума, М. Д. Дурманова, А. А. Тілле, С. О. Письменського, Ю. А . Пономаренка, О. Б. Сахарова, І. І. Солодкіна, А. Є. Якубова та інших), обмежимось вказівкою на те, що для цілей нашої роботи будемо використовувати розуміння lex in mitius Ю. А. Пономаренком [1, с. 162-165] та Є. О. Письменським [2, с. 292-293];
2) алгоритм пом'якшення покарання визначений у ч. 3 ст. 74 КК як двоетапний: спочатку суд має знизити призначену засудженому міру покарання до максимальної межі санкції нового закону, потім - зарахувати відбуте засудженим покарання. При цьому, якщо максимальна межа санкції нового закону передбачає більш м'який вид покарання, відбуте засудженим покарання зараховується з перерахуванням за правилами, встановленими частиною першою статті 72 цього Кодексу;

3) 3 огляду на можливі варіанти зміни санкції у бік покращення становища засудженого, формулювання «максимальна межа покарання, встановленого санкцією» в принципі може характеризувати як основне, так i додаткове покарання. Більш конкретний зміст поняття «максимальна межа покарання, встановленого санкцією» для основного покарання може бути визначений таким чином: а) це максимальний строк або розмір основного покарання, передбаченого санкцією статті (санкцією частини статті) Особливої частини цього Кодексу, якщо відповідна санкція містить лише один вид основного покарання; б) це максимальний строк або розмір найбільш суворого виду основного покарання, передбаченого санкцією статті (санкцією частини статті) Особливої частини цього Кодексу, якщо відповідна санкція $€$ альтернативною і передбачає декілька видів основного покарання. Для додаткового покарання - «максимальна межа покарання, встановленого санкцією нового закону» означає максимальний строк або розмір для кожного виду додаткового покарання.

Застосування положень ч. 3 ст. 74 КК може бути проблематичним у таких ситуаціях:

1) якщо максимальна межа покарання, встановлена санкцією нового закону, передбачає такий вид покарання, який в принципі не може бути призначений конкретній особі з огляду на її вік, стать, стан здоров’я, вид професійної діяльності, наявність дітей певного віку та інші фактори, визначені статтями Розділу X Загальної частини КК, але водночас санкція нового закону містить альтернативні види покарання, допустимі для призначення відповідній особі;

2) якщо санкція нового закону передбачатиме лише такі покарання, жодне з яких не може бути призначене конкретній особі з урахуванням обмежень, встановлених положеннями Розділу Х Загальної частини КК;

3) якщо максимальна межа покарання, встановлена санкцією нового закону, становить більш м'який вид покарання і перерахування цього виду покарання в інші за 
правилами, встановленими ч. 1 ст. 72 КК, в принципі не можливо (йдеться про такі види покарання, як штраф та позбавлення права обіймати певні посади або займатися певною діяльністю);

4) якщо міра покарання була визначена особі за правилами, передбаченими ст.ст. 70, $71 \mathrm{KK}$;

5) якщо засуджений був звільнений від відбування призначеного йому основного покарання з випробуванням.

Питання про те, як застосовувати положення ч. 3 ст. 74 КК у випадках, коли максимальна межа, встановлена санкцією нового закону, становить такий вид покарання, який в принципі не може бути призначений конкретній особі з огляду на її вік, стать, стан здоров'я, вид професійної діяльності, наявність дітей певного віку та інші фактори, визначені статтями Розділу X Загальної частини КК, на нормативному і правозастосовному рівні наразі не вирішене. На нашу думку, встановлення можливих шляхів розв'язання цієї проблеми має відбуватись, в тому числі, з урахуванням практики подолання схожих ситуацій на попередніх етапах застосування правової норми. Зокрема, у випадках, коли санкція нового закону передбачає лише такі покарання, жодне з яких не може бути призначене конкретній особі з урахуванням обмежень, встановлених положеннями Розділу Х Загальної частини КК, суд має орієнтуватися на підхід, визначений у п. 18 постанови Пленуму Верховного Суду України від 06.04.2004 р. № 5 «Про

${ }^{1}$ Суду України від 06.04.2004 р. № 5: «Якщо санкцією закону, за яким засуджується неповнолітній, передбачено лише такі види покарань, які з огляду на вік підсудного чи його стан не можуть до нього застосовуватися, суд звільняе його від кримінальної відповідальності із застосуванням примусових заходів виховного характеру, або відповідно до ст. 7 КПК закриває справу і звільняе його від кримінальної відповідальності, або постановляє обвинувальний вирок і звільняє засудженого від покарання».

2 абз 2 п. 6-1 постанови ПВСУ № 7 від 24.10 .2003 р. : «Правила частин 2 і 3 статті 68 КК (2341-14) не можуть бути застосовані при призначенні покарання особі, яка у віці 18 і більше років вчинила злочин, за який передбачено найбільш суворий вид покарання - довічне позбавлення волі, оскільки цей вид покарання є таким, що виключає можливість визначення його половини чи двох третин. Однак до осіб, які вчинили готування до такого злочину або вчинення замаху на злочин у віці до 18 років, і до осіб у віці понад 65 років, а також до жінок, що були у стані вагітності під час вчинення злочину або на момент постановлення вироку, і яким не може бути призначено покарання у виді довічного позбавлення волі, мають застосовуватися вимоги частин 2 і 3 статті 68 КК (2341-14), виходячи 3 максимального покарання позбавлення волі на певний строк». практику застосування судами України законодавства у справах про злочини неповнолітніх» ${ }^{1}$. Адаптація відповідного положення до визначеної вище ситуації передбачатиме обов'язок суду звільнити засудженого від призначеного йому основного покарання або від відбування невідбутої частини відповідного покарання.

Якщо ж санкція нового закону містить також альтернативні види основного покарання, допустимі для конкретної особі, вирішення питання про пом'якшення призначеного такій особі покарання може відбуватись з урахуванням підходу, зазначеного в абз. 2 п. 6-1 постанови ПВСУ № 7 від 24.10 .2003 р. «Про практику призначення судами кримінального покарання» ${ }^{2}$. Принагідно відзначимо, що розширене тлумачення нормативного змісту положень частин 2,3 ст. 68 КК стосовно поняття «найбільш суворого виду покарання, передбаченого санкцією статті (санкцією частини статті) Oсобливої частини цього Кодексу», на нашу думку, є неприйнятним для ряду випадків призначення покарання (ч.ч. 2, 3 ст. 68, ч. 3 т. 43, ст. 69-1 КК). Водночас загальне положення про зворотну дію кримінального закону, сформульоване у ч. 1 ст. 5 КК, вимагає його реалізації і у наведеній вище проблемній ситуації. Варіант із пом'якшенням призначеного покарання до максимального строку або розміру найбільш суворого для конкретної особи виду покарання у новій санкції, на нашу думку, $є$ цілком допустимим.

Наступною проблемою застосування ч. 3 ст. 74 КК є ситуації, коли засудженому за старим законом було призначене покарання у виді громадських робіт, виправних робіт, арешту, обмеження волі, позбавлення волі, а санкцією нового закону за відповідне діяння встановлено штраф чи позбавлення права обіймати певні посади або займатися певною діяльністю. Визначаючи можливі варіанти вирішення цього питання, слід мати на увазі підхід, сформульований у п. 2 Прикінцевих та перехідних положень Закону № 4025-VI від 15.11.2011 р. «Про внесення змін до деяких законодавчих актів України щодо гуманізації відповідальності за правопорушення у сфері господарської діяльності». Зазначеним законом були змінені санкції цілого ряду норм; характер цих змін переважно передбачав збереження у «нових санкціях» лише одного виду основного покарання - штрафу. 3 огляду на масовий характер змінених санкцій, законодавець у п. 2 Прикінцевих та перехідних положень визначив специфічні правила перерахунку покарань у виді громадських робіт, виправних робіт, арешту, обмеження волі, позбавлення волі на покарання 
у вигляді штрафу: «особам, що відбувають покарання у виді громадських чи виправних робіт, арешту, обмеження чи позбавлення волі за вчинення злочинів, за які цим Законом передбачається встановлення основного покарання лише у виді штрафу, невідбута частина покарання знижується до відповідного розміру штрафу. Розмір штрафу особам, що відбувають покарання у виді позбавлення волі, визначається виходячи із строку невідбутого покарання шляхом його перерахунку за правилами, встановленими частиною п'ятою статті 53 Кримінального кодексу України. Розмір штрафу особам, що відбувають покарання у виді громадських чи виправних робіт, арешту або обмеження волі, визначається виходячи із строку невідбутого покарання шляхом його перерахунку на покарання у виді позбавлення волі за правилами, встановленими частиною першою статті 72 Кримінального кодексу України, та наступного перерахунку за правилами, встановленими частиною п'ятою статті 53 Кримінального кодексу України». Іншими словами, пом'якшення призначеного засудженому покарання у виді позбавлення волі за цим положенням мало відбуватись шляхом заміни його невідбутої частини штрафом за правилом: один день позбавлення волі дорівнює восьми неоподатковуваним мінімумам доходів громадян Алгоритм перерахунку невідбутої частини покарання у виді громадських робіт, виправних робіт, арешту, обмеження волі на штраф був більш складний і передбачав перерахунок у два етапи: спочатку перерахунок невідбутої частини відповідного покарання у позбавлення волі, потім - перерахунок позбавлення волі у штраф за наведеним вище правилом. 3 огляду на те, що у ч. 5 ст. 53 КК також визначено співвідношення штрафу із виправними роботами і громадськими роботами, «двоетапний» алгоритм принаймні викликає запитання.

Проте основне зауваження до змісту п. 2 є значно серйознішим. Навіть поверховий аналіз відповідного положення дозволяє поставити під сумнів запропонований підхід 3 огляду на його невідповідність ч. 3 ст. 74 КК: по-перше, у вказаній нормі кримінального закону йдеться про обов'язок суду пом'якшити призначену засу дженому міру покарання, а не його невідбуту частину. Отже у пункті 2 Прикінцевих і перехідних положень відбувається підміна понять («зарахування відбутого покарання» - «заміна невідбутої частини покарання»); у конкретних випадках застосування визначеного цим пунктом підходу може призвести до погіршення становища засудженого порівняно із тим, якщо був би реалізований «загальний» алгоритм дій суду, передбачений ч. 3 ст. 74 КК (див. вище). Наприклад, санкція ч. 2 ст. 203-1 КК до набрання чинності Законом № 4025-VI від 15.11.2011 р. передбачала один вид основного покарання - позбавлення волі на строк від двох до п'яти років; санкція цієї ж статті в редакції Закону № 4025-VI передбачає штраф від п'яти тисяч до десяти тисяч неоподатковуваних мінімумів доходів громадян. Якщо особі, яка засуджена за часів дії старого закону, було призначене покарання у виді позбавлення волі на строк п'ять років, з яких на момент набрання чинності новим законом особа відбула чотири роки, то, за змістом п. 2 Прикінцевих та перехідних положень, невідбута частина покарання (1 рік) замінюється штрафом у співвідношенні «один день позбавлення волі дорівнює вісім неоподатковуваних мінімумів доходів громадян»: 365 днів * 8 н.м.д.г. $=2920$ н.м.д.г. Тепер спробуємо застосувати визначений ч. 3 ст. 74 КК загальний алгоритм пом'якшення призначеного покарання, скориставшись для перерахунку позбавлення волі у штраф тим же співвідношенням: спочатку знижуємо призначену засудженому міру покарання до максимальної межі санкції нового закону - штрафу у розмірі 10000 н.м.д.г., потім зараховуємо відбуте засудженим покарання -4 роки або 1461 день * 8 н.м.д.г. $=$ 11688 н.м.д.г. Як бачимо, відбуте покарання визначене шляхом перерахунку позбавлення волі у штраф перевищує максимальний розмір штрафу у новій санкції, отже засуджений має бути звільнений від відбування покарання. Насправді, ми не пропонуємо перераховувати позбавлення волі чи інші покарання у штраф; приклад наведено лише для демонстрації некоректності підходу, сформульованого у п. 2 Прикінцевих та перехідних положень Закону № 4025-VI від 15.11.2011 p.

По-друге, в силу прямої вказівки ч. 3 ст. 74 КК, у разі якщо максимальна межа санкції нового закону передбачає більш м'який вид покарання, відбуте засудженим покарання зараховується з перерахуванням за правилами, встановленими частиною першою статті 72 цього Кодексу. Своєю чергою, ч. 1 ст. 72 КК не визначає співвідношення штрафу і позбавлення права обіймати певні посади або займатись певними видами діяльності до інших видів покарання. Більш того, системне тлумачення ряду інших положень КК (ст. 55, ч. 3 ст. 72 , ч. 5 ст. 72 КК) дозволяе зробити висновок про те, що покарання у виді штрафу і позбавлення права обіймати певні посади або займатись певними видами діяльності мають певну специфіку, яка не дозволяє перераховувати їх в інші види покарання, 
та навпаки. Отже, визначені у п. 2 Прикінцевих та перехідних положень Закону № 4025-VI від 15.11. 2011 р. правила пом'якшення призначеного засудженому покарання можуть застосовуватись тільки до випадків, передбачених цим Законом, i не повинні поширюватись на всі схожі ситуації. На нашу думку, для випадків, коли засудженому за старим законом було призначене покарання у виді громадських робіт, виправних робіт, арешту, обмеження волі, позбавлення волі, а санкцією нового закону за відповідне діяння встановлено штраф чи позбавлення права обіймати певні посади або займатися певною діяльністю, у КК доцільно закріпити положення загального змісту на кшталт того, що визначене ч. 5 ст. 72 КК, i надати суду дискреційні повноваження пом'якшити покарання або повністю звільнити засудженого від його відбування.

Пропонуємо перейти до розгляду наступного питання: яким чином мають застосовуватись положення ч. 3 ст. 74 КК, якщо міра покарання засудженому була визначена за правилами, передбаченими ст.ст. 70, 71 КК, тобто за сукупністю злочинів чи сукупністю вироків. Нормативним орієнтиром для вирішення поставленого питання міг би вважатись підхід, сформульований у вже згаданих вище Прикінцевих та перехідних положеннях Закону № 4025-VI від 15.11.2011 р. У п. 3 Прикінцевих положень зазначається: «Особам, що відбувають покарання у виді громадських чи виправних робіт, арешту, обмеження чи позбавлення волі, призначене за сукупністю злочинів, один або кілька з яких згідно з цим Законом карається основним покаранням лише у виді штрафу, невідбута частина покарання знижується до відповідного розміру штрафу тільки у випадку, якщо за такий злочин було призначене більш суворе покарання з числа покарань за злочини сукупності. Таке ж правило застосовується при вирішенні питання щодо зниження покарання до відповідного розміру штрафу особам, які відбувають покарання, призначене за сукупністю вироків». Як бачимо, у цьому положенні, так само, як і у п. 2, зберігається хибний підхід щодо підміни понять «зарахування відбутого покарання» - «заміна невідбутої частини покарання». До того ж, на відміну від розглянутих вище положень п. 2, тут незрозуміло, що мається на увазі під «відповідним розміром штрафу»? Якщо це максимальний розмір штрафу у санкції нового закону, то чи можна взагалі говорити про пом'якшення призначеного покарання, коли його невідбута частина, яка може бути і зовсім незначною, буде начебто «зменшуватись» до максимальної межі санкції. До того ж очевидними є неповнота і фрагментарність вирішення питання про пом'якшення покарання, призначеного за сукупністю злочинів чи вироків, у згаданому п. 3: цим положенням передбачене пом'якшення невідбутої частини «сукупного» покарання тільки тоді, коли змінювалась санкція тієї статті (частини статті) Особливої частини КК, за якою особі було призначене більш суворе покарання $з$ тих, що призначені за сукупністю, i не передбачено варіанти дій суду у разі, коли зменшилась караність інших злочинів. 3 огляду на наведені вище вади, вважаємо, що запропонований у п. 3 Прикінцевих та перехідних положень Закону № 4025-VI від 15.11.2011 р. підхід щодо застосування ч. 3 ст. 74 КК стосовно осіб, що відбувають покарання за сукупністю злочинів чи вироків, може поширюватись тільки на випадки, передбачені у самому Законі.

Якщо не брати до уваги визначений вище явний «ляп» щодо заміни невідбутої частини покарання, а не пом'якшення призначеного покарання в цілому, спробуємо встановити, чи може застосовуватись підхід, за яким остаточна міра покарання, призначеного за сукупністю злочинів чи вироків, буде зменшуватись до максимальної межі покарання за однією із санкцій статей (частин статей), за якою засуджено особу, не беручи до уваги принцип, за яким було визначене «сукупне» покарання. Зауважимо, що сам принцип призначення остаточного покарання вибраний і вмотивований у судовому рішенні, яке, по-перше, набрало законної сили, а по-друге, не скасоване. Постає питання: чи є досить обгрунтованим варіант зменшення остаточного покарання, визначеного шляхом складання або приєднання, до максимальної межі караності одного злочину? Вважаємо, що ні. На наш погляд, саме принцип призначення остаточного покарання вказує на те, наскільки міра покарання за окремий злочин врахована в остаточному покаранні, отже повинен мати вирішальне значення щодо питання про обов'язковість пом'якшення призначеного покарання внаслідок зміни караності одного чи декількох посягань. Коментуючи п. 5 Розділу II Прикінцевих та перехідних положень до КК 2001 р., С. Д. Шапченко запропонував досить складний варіант застосування положень частин 2, 3 ст. 74 КК щодо засудженого за сукупністю злочинів чи сукупністю вироків [4, с. 836-837]. Визначений С. Д. Шапченком підхід передбачав урахування принципу, за яким було визначене остаточне покарання При цьому у разі призначення остаточного покарання шляхом часткового складання вимагалось встановлювати «масову долю» 
кожного $з$ покарань, включених до остаточного. Визнаючи коректність запропонованого С. Д. Шапченком підходу, відзначимо також його складність у практичному застосуванні.

Пропонуючи свій варіант вирішення проблеми, будемо виходити 3 того, що такий варіант, по-перше, має бути універсальним - незалежним від виду призначеного покарання та покарання, передбаченого санкцією нового закону, а по-друге, повинен враховувати принцип остаточного покарання, призначеного за сукупністю злочинів чи вироків. На нашу думку, можливим $€$ такий підхід:

1) якщо остаточне покарання за сукупністю злочинів чи вироків було визначене шляхом поглинення, а новим кримінальним законом зменшена караність того злочину (злочинів), за який (які) було призначене менш суворе покарання, ч. 3 ст. 74 КК не застосовується i призначене засудженому покарання не пом'якшується;

2) якщо остаточне покарання за сукупністю злочинів чи вироків було визначене шляхом поглинення, а новим кримінальним законом зменшена караність того злочину, за який було призначене більш суворе покарання, призначена засудженому міра остаточного покарання знижується до максимальної межі покарання, встановленої санкцією нового закону;

3) якщо остаточне покарання за сукупністю злочинів чи вироків було визначене шляхом повного або часткового складання (приєднання) і новим кримінальним законом зменшена караність будь-якого зі злочинів, що входять до сукупності, спочатку призначена засудженому міра покарання за окремий злочин знижується до максимальної межі покарання, встановленої санкцією нового закону, потім - остаточна міра покарання визначається за тим же принципом, який був вибраний і обгрунтований в обвинувальному вироку суду.

Останнє питання - про застосування положень ч. 3 ст. 74 КК, якщо засуджений був звільнений від відбування призначеного йому основного покарання з випробуванням. Досліджуючи таку ситуацію, потрібно взяти до уваги таке: по-перше, призначення покарання і рішення про звільнення особи від відбування покарання 3 випробуванням $€$ взаємопов'язаними, послідовними, проте різними етапами застосування кримінально-правової норми; по-друге, встановлювати співвідношення між реальним та «умовним» покаранням (порівнювати їх) некоректно, хоча слід вказати, що умовне незастосування покарання є більш «приві- лейованою» формою кримінальною відповідальності, ніж реальне відбування покарання. Виходячи 3 цього, варто визнати, що зменшення караності діяння за новим кримінальним законом в принципі мало би передбачати пом'якшення призначеного покарання. Водночас за наявності такого, що набрало законної сили, рішення суду про звільнення від відбування основного покарання з випробуванням і відсутності підстав для перегляду цього рішення зменшення призначеного покарання видається, принаймні на перший погляд, недоцільним. Тим більше, що пом'якшення призначеного засудженому покарання може передбачати заміну його виду таким, який в принципі унеможливлює звільнення 3 випробуванням (див. ч. ст. ст. 75, 104 КК). 3 іншого боку, одним із можливих правових наслідків звільнення 3 випробуванням є направлення засудженого для відбування призначеного покарання (ч. 2 ст. 78 КК). Реалізація такого варіанту вимагатиме здійснити зменшення призначеного покарання до максимальної межі санкції нового закону. Орієнтуючись на підхід, сформульований у п. 4 Прикінцевих та перехідних положень Закону № 4025-VI від 15.11.2011р., пропонуємо: при зменшенні караності злочину, за вчинення якого засуджений був звільнений від відбування призначеного йому основного покарання 3 випробуванням, питання про застосування положень ч. 3 ст. 74 КК вирішувати тільки у випадках направлення засудженого для реального відбування призначеного покарання.

\section{Висновки}

Конкретні рекомендації щодо застосування положень ч. 3 ст. 74 КК в окремих кримінально-правових ситуаціях доцільно визначити принаймні на рівні правових висновків (правових позицій) Верховного Суду.

\section{Список використаних джерел:}

1. Пономаренко Ю.А. Чинність і дія кримінального закону в часі : монографія. Київ, 2005. $288 \mathrm{c}$.

2. Письменський Є.О. Звільнення від покарання та його відбування: проблеми кримінального законодавства та практики його застосування : монографія. Луганськ : Віртуальна реальність, 2011. $388 \mathrm{c}$.

3. Горох О.П. Сучасні кримінально-правові проблеми звільнення від покарання та його відбування : монографія. Київ : ВД «Дакор», 2019. 676 с.

4. Науково-практичний коментар до Кримінального кодексу України. 4-те вид., переробл. та доповн. / відп. ред. С.С. Яценко. Київ : А.С.К., $2005.848 \mathrm{c}$ 
The article dedicated to the practical aspects of applying the institution of punishment mitigation due to the retroactive action of criminal law. The legal nature and normative content of part 3 of Art. 74 of the Criminal Code of the provision on reduction of the sentence of the convict is examined, the algorithm of mitigation of punishment according to part 3 of Art. 74 of the Criminal Code is established, the specific meaning of the concept of "maximum penalty limit set by the sanction of the new law" defined. According to the author, the application of the provisions of Part 3 of Art. 74 of the Criminal Code can be complicated in the next cases: 1) if the maximum penalty established by the sanction of the new law provides for a type of punishment that can not be assigned at all to a specific person, given theirs age, gender, health, type of professional activities, the presence of children of a certain age and other factors as defined in the articles of Section X of the General Part of the Criminal Code, but at the same time the sanction of the new law contains alternative types of punishment possible to assign to such a person; 2) if the sanction of the new law provides only for such penalties, none of which can be assigned to a specific person according to the restrictions established by the provisions of Section $X$ of the General Part of the Criminal Code; 3) if the maximum punishment limit established by the sanction of the new law is a softer kind of punishment and the transfer of this type of punishment to other according to the rules established by Part 1 of Art. 72 of the Criminal Code is not possible at all (considering punishments such as fines and deprivation of the right to occupy certain positions or engage in certain activities); 4) if the punishment was assigned to a person according to the rules stipulated by Art. 70, 71 of the Criminal Code; 5) if the convicted person has been released from serving his basic sentence on probation. The article offers specific solutions to such problem cases.

Key words: retroactive action of criminal law, criminal law, criminal liability, mitigation of criminal liability, mitigation of sentencing. 